POLISH POLITICAL SCIENCE

VOL XXXIX 2010

PL ISSN 0208-7375

\title{
REVIEWS
}

\section{Book review: Andrzej Antoszewski, Parties and Party Systems in the EU Member States at the Turn of the 20th and 21st Centuries, Wydawnictwo Adam Marszałek, Toruń 2010, pp. 376}

\author{
by Jerzy Sielski
}

The book by Andrzej Antoszewski consists of three parts. The first of them is of a theoretical character. The author analyses the concept of liberal democracy, trying to present the problems connected with this issue. In the second chapter, he discusses the idea of a party as a political institution and presents how the social and cultural changes influence its activity. In a very interesting way, he describes the conditions in which political parties in Central and Eastern Europe were established. He wonders whether the different circumstances in which they were formed have affected the way they operate and their mutual relations.

In the second part, the author tries to present the main "families" of the political parties functioning in the European Union members states, which take part in the political competition in the electoral, the parliamentary and the cabinet arenas (socialist and social democratic parties; conservative and Christian democratic; liberal; ecological; radical ones). On the basis of 123 election results (73 in Western Europe and 50 in Eastern Europe), held in the years 1990-2008, he measures their strength and examines how their electoral support has changed as well as how relevant each of them is in the cabinet arena. The composition of 237 governments functioning in all 27 European Union member states between 1.01.1990 and 30.06.2008 constitutes the empirical foundation for these considerations. The author analyses the actual power that particular parties and their coalitions have on the political scene. 
The third part presents the theoretical and practical analysis of the way that party systems in the European Union countries function. First, the author operationalises the concept of the theory of party systems, distinguishing three system levels (electoral, parliamentary and cabinet) as well as he analyses how they are related by using D. Easton's systems theory. He tries to present the essence of inputs (contributions) to a system and its outputs (products). The fundamental question that the author wants to answer is: How does a party system, understood as the interactions of political parties, adapts to changes, especially to the increasing electoral unsteadiness. On the basis of the literature of the subject, the results of parliamentary elections and the process of forming governments, he attempts to find an answer to the question in what way the stability and instability of party systems is expressed. He concludes that there are no significant differences between the mechanisms of party systems in Western and Eastern Europe. That is why he formulates a hypothesis of the convergence of party systems in the European Union countries. Obviously, the author emphasises that it is only a hypothesis, which may turn out to be true or not.

The book under review is of a pioneer character in the Polish scientific and publishing market, as it is the first monograph which treats the issues of parties and party systems of the European countries looking at Western and Eastern Europe as one whole.

The research matter is complicated and extensive, because it encompasses 27 countries, therefore, 27 party systems over the timespan of 19 years. Moreover, parties and party systems are subject to constant rotation, some of them disappear from the political scene, others come into being. Despite these facts, the author shows great confidence and big factual knowledge. As a reviewer of a number of scientific papers and doctoral theses, I really admire the author's methodological, theoretical and descriptive aptitude and confidence. It is a mark of an excellent scholar. The author supports his conclusions and research hypotheses with a thorough examination from the point of view of political science. To make his argument more clear, he always precedes his analysis with a table including the data concerning specific political parties or a party system of a given research area. There are "only" 80 tables in the book, really a trifle! It should be emphasised that the literature in this area is very extensive, and the publications of Polish authors constitute only a small part of it. On the basis of all those facts, I can state that the book under review marks a very important stage in the author's scientific career. It sums up his scientific activity because, so far, he has been writing about party systems of Western and Eastern Europe separately 
(see for example: A. Antoszewski, R. Herbut (ed.) West European Democracies. Comparative Analysis, Wrocław 1997: A. Antoszewski, Political parties of Central and Eastern Europe, Poznan - Wrocław 2005). Now we have one work, which, on the one hand, tries to compare both party systems in separation, find differences and similarities. On the other hand, for the first time, both systems are discussed together, as one system.

These are both advantages and disadvantages. Of course, I have some comments, I have a different opinion on some issues. But first I had to "give to Caesar the things which are Caesar's", and now I can argue with the author.

The author focuses on the analysis of the relevant political parties. Therefore, he does not examine all political parties, but only those which have had significant influence in the political and the cabinet arena. I must admit it is logical and methodologically correct. However, I should ask a question if it would be at all possible to look into all political parties of the European Union. It seems a great challenge.

The typology of the political parties under examination is another important problem. The author divided them into two main streams: the right-wing and the left-wing. This is where the problem lies. Are there no centre parties, not mentioning separated parties, unconnected to the right or the left wing? Moreover, he forgot about the national orientation, classifying all parties of this type as the radical rightwing ones. I personally distinguish between parties of the extreme right-wing and national parties. There is a similar situation on the left side of the political scene, where, in my opinion, some socialist or communist parties with a Eurocommunist profile are in fact radical parties. Likewise, can Polish ZChN (Christian National Union) be classified as a Christian democratic party? I believe it cannot. To conclude, in my opinion, the author ignored the multitude of streams on the political scene. The question arises whether he had the right to such interpretations. In defence of the author, it can be said that each typology is subject to discussion. None of them will meet all requirements of the correct classification, as it is difficult to interpret the political reality in an ideal way. It is too complex and it is always redefined in a different manner after some time. That is why, despite my criticism, I find the work quite lucid and clear, which makes it possible to interpret the political entities under examination in the accurate and interesting way.

To sum up, I can definitely say that the paper under review is one of the better books, if not the only one, which interpret the new political space of Western and Central-Eastern Europe in a complex way. 